\title{
PKM KELOMPOK PERAJIN RENDO BANGKU DI NAGARI KOTO GADANG KABUPATEN AGAM SUMATERA BARAT
}

\author{
Rahmad Washinton' ${ }^{1}$, Ranelis ${ }^{2}$, Kendall Malik ${ }^{3}$ \\ 1)Program Studi Seni Kriya/Jurusan Kriya/ISI Padangpanjang \\ 2)Program Studi Pendidikan Kriya/Jurusan Kriya/ISI Padangpanjang \\ 3)Program Studi Desain Komunikasi Visual/Jurusan Desain/ISI Padangpanjang \\ Jalan Bahder Johan No.35 Padangpanjang - Sumatera Barat/Kodepos 27128 \\ Email : rahmad.washinton@gmail.com ${ }^{1)}$, ranelis@gmail.com ${ }^{2)}$, kendall.malik@gmail.com ${ }^{3)}$
}

\begin{abstract}
ABSTRAK
Kerajinan rendo bangku merupakan mata pencaharian pokok perekonomian sebahagian masyarakat Koto Gadang. Usaha rendo bangku ini telah membudi daya di lingkungan masyarakat Koto Gadang. Terutama kaum ibu, remaja putri juga anak-anak yang merupakan generasi penerus kerajinan rendo bangku. Rendo bangku yang dibuat oleh perajin Koto Gadang hanya terbatas pada perlengkapan adat yaitu untuk hiasan tepi selendang wanita Koto Gadang. Perajin rendo bangku Koto Gadang dalam memasarkan produknya hanya di daerah Koto Gadang itu sendiri karena kebutuhan adat bagi masyarakat Koto Gadang pada umumnya. Pemasaran rendo Koto Gadang masih sangat terbatas sehingga rendo Koto Gadang belum dapat diketahui oleh masyarakat lain pada umumnya. Tujuan program PKM ini adalah memberikan pelatihan pengembangan desain motif dan produk, untuk meningkatkan daya saing di pasar global ataupun internasional dan juga untuk meningkatkan taraf hidup perajin rendo bangku Koto Gadang. Melihat potensi tersebut untuk meningkatkan pendapatan para pengrajin perlu adanya pengembangan desain motif, produk dan pemasaran produk rendo bangku Koto Gadang.
\end{abstract}

Kata kunci : Rendo Bangku, desain, motif, produk.

\section{PENDAHULUAN}

Nagari Koto Gadang merupakan bagian dari kecamatan IV Koto, kabupaten Agam, dengan batasbatas wilayah sebagai berikut: Di sebelah barat terdapat kota Bukittinggi yang dibatasi oleh lembah Ngarai Sianok; sebelah utara berbatasan dengan desa Sianok VI suku, di sebelah selatan berbatasan dengan desa Koto Tuo; di sebelah barat berbatasan dengan Koto Panjang; dan di sebelah timur berbatasan dengan desa Guguak Tabek Sarojo (Etek, 2007: 37).

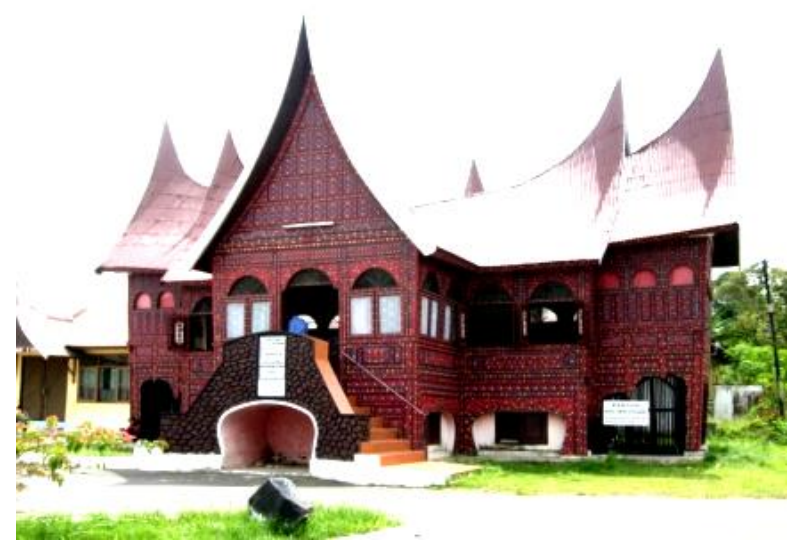

Gambar 1. Kantor balai adat nagari jorong Koto Gadang.

Menurut sejarahnya sebelum Minangkabau berada di bawah kolonialis Belanda, mata pencaharian utama masyarakat Koto Gadang adalah bertani di sawah, berladang, beternak, bertukang kayu, perajin sulam , rendo dan bertukang emas. Masyarakat Koto Gadang ahli dalam membuat barang seni kerajinan, seperti menyulam, merendo dan membuat seni kerajinan perak. Usaha seni kerajinan 
rendo bangku sebagai salah satu sektor penunjang kehidupan masyarakat, perkembangannya cukup baik.

Rendo bangku merupakan salah satu seni tradisi yang menjadi ciri khas budaya Koto Gadang. Kerajinan rendo bangku Koto gadang ini dimulai sejak berdirinya sekolah kerajinan Amai Setia pada tahun 1911, yang diperkenalkan oleh para isteri Belanda di zaman penjajahan (Sita Dewi Razni dkk, 2011: 86). Kerajinan rendo bangku ini sama dengan kerajinan renda yang ada pada masing-masing daerah. Hanya saja bagi masyarakat Koto Gadang dinamakan rendo bangku karena dalam proses pembuatannya memerlukan alat untuk dudukan yang mirip dengan bangku kecil. Sedangkan bagi daerah lain dalam pembuatannya menggunakan jarum renda. Dahulunya pekerjaan merendo merupakan pekerjaan sampingan bagi wanita Koto Gadang setelah bertani dan melakukan pekerjaan rumah tangga. Namun, sejak tiga dasawarsa belakangan ini usaha kerajinan rendo bangku menjadi sumber utama bagi kehidupan masyarakat Koto Gadang yang ditekuni secara profesional. Berkembangnya kerajinan rendo bangku di Koto Gadang telah menjadikan daerah ini sering dikunjungi oleh wisatawan, baik dari dalam ataupun luar negeri. Namun bersamaan dengan itu para perajin rendo bangku Koto Gadang merasa kewalahan dengan hal tersebut, dikarenakan bentuk motif rendo yang dihasilkan para perajin masih sangat monoton dengan motif dan bentuk produk-produk yang sama yaitu berupa hiasan di tepi selendang, tatanan gelas, dan alas keramik dengan bentuk motif rendo yang masih turun-temurun berupa bentuk bunga dan daun.Terkait denganitu kerajinan rendo bangku sebagai produk sosial dan modal dasar dalam melahirkan perubahan untuk meningkatkan perekonomian dan kesejahteraan masyarakat Koto Gadang.

Keahlian perajin rendo bangku Koto Gadang dalam merendo tidak diragukan lagi, tetapi dalam bidang lain seperti pengembangan desain motif dan produk masih sangat minim dan produk yang dibuat masih bersifat pengulangan - pengulangan bentuk semata yang didapat secara turun-temurun. Sehingga konsumen merasa jenuh dengan kurangnya variasi motif dan produk kerajinan rendo bangku yang dihasilkan oleh para perajin rendo bangku Koto Gadang. Permasalahan mitra ini juga terlihat dari hasil penelitian yang penulis lakukan bersama timpada tahun 2015 tentang rendo bangku Koto gadang.Dari hasil penelitian terlihat bahwa kemampuan para perajin baru sampai pada tahapteknis membuat rendo, sedangkan untuk proses produksi masihmembutuhkan pembinaan dan pelatihan lebih lanjut. Terutama untuk manajemen produksi, pengembangan desain motif, desain produk dan manajemen pemasaran nantinya setelahproduk tersebut selesai di produksi.Untuk meningkatkan pendapatan para pengrajin perluadanya pengembangan desain motif dan produk, dan perluasan pemasaran produk rendo bangku Koto Gadang. Sehingga produk yangdihasilkan bisa mengikuti selera pasar dan dapat meningkatkan tarap hidup masyarakat baik peserta pelatihan maupun masyarakat di sekitarnya.

\section{METODE PELAKSANAAN PENGABDIAN}

Pengembangan industri kerajinan rendo bangku Koto Gadang dapat dijadikan usaha yang memiliki prospek bisnis yang menjanjikan. Industri yang ada saat ini, belum memperhatikan pengembangan desain motif yang memiliki karakteristik dan ciri kedaerahan. Di antaranya desain motif belum memperhatikan permintaan pasar. Begitu juga dengan proses pembuatan rendo, masih belum variatif dan dioptimalkan dengan baik sebagai asesoris busana dan produk cenderamata sehingga desain motif dan variasi dari produk rendo bangku yang dihasilkan tidak banyak diminati konsumen.

Rendo bangku yang dihasilkan di daerah Koto Gadang ini dibuat dengan alat tradisional yang disebut dengan bangku yaitu sebuah alat yang berbentuk bundar dengan memakai alas triplek yang berbentuk empat persegi yang dikasih lobang di tengah dan ditutup dengan kain yang berwarna putih (Sita Dewi Razni dkk, 2011: 89).Peluang pengembangan industri ini dapat disentuh melalui pengembangan desain motif dan produk agar menemukan inovasi dankreativitas bagi perajin rendo yang ada di Koto Gadang. Kerajinan rendo bangku ini akan dikembangkan dengan peningkatan motif dan produk yang lebih kreatif dan inovatif. Untuk meningkatkan kemampuan perajin rendo bangku dalam menghasilkan desain motif dan produk yang kreatif dan inovatif, maka dilakukan kegiatan berupa: 


\subsection{Sosialisasi}

a). Metode Pelaksanaan

Metode pelaksanaan ini dilakukan dengan cara memberikan penyuluhan kepada perajin tentang peningkatan kualitas rendo bangku melalui pengembangandesain motif, pengembangan produk dan pengembangan pemasaran rendo bangku. Karena dengan dilakukan pengembangan desain motif yang berkualitas bisa meningkatkan nilai jual dari produk rendo yang dihasilkan di Koto Gadang.

b). Partisipasi Mitra

Partisipasi mitra dalam pelaksanaan program ditunjukkan dengan adanyadukungan dan kesanggupan kerja sama, sebagai mitra dengan tim dari ISIPadangpanjang dalam penerapan Ipteks bagi masyarakat. Kemudian partisipasi mitra dalam kegiatan PKM ini adalah berpartisipasi dalam hal persiapan yaitu menyediakan tempat untukdilakukannya sosialisasi pengembangan desain motif dan produk rendo bangku. Mengumpulkan para perajin sebagai peserta untuk diberikan pemahaman dan ilmu pengetahuan tentang desain kreatif dan inovatif.

\subsection{Pelatihan}

a). Metode Pelaksanaan

Metode pelaksanaan dilakukan dengan cara ceramah dan demonstrasi yaitu memberikan pemahaman dan penjelasan kepada perajin bahwa perlu sekali dilakukan pengembangan desain motif dan produk rendo bangku di Koto Gadang untuk meningkatkan kualitas darikerajinan rendo bangku yang dihasilkan oleh perajin Koto Gadang dengan ciri khas daerah Minangkabau. Memberikan penjelasan kepada perajin tentang peralatan yang dibutuhkan untuk melaksanakan kegiatan tersebut. Peralatan yang dibutuhkan adalah perangkatdesain.

Peningkatan kualitas desain motif dan produk dilakukandengan cara mengambil ikon-ikon local genius yang ada di Koto Gadang.Pengembangan desin motif dibuat dengan inovasi yang beragam sesuaidengan kebutuhan pasar. Pelatihan peningkatan kualitas danpengembangan desain motif dengan demonstrasi langsung pada perajin.Beragam jenis pengolahan motif dan inovasi yang bisa dibuat untuk pengembangan kerajinan rendo bangku Koto Gadang. Pada prinsipnya adalahpengolahan desain motif sehingga menjadi karakteristik dan ciri daerahyang ada di Solok Selatan. Untuk pengembangan desain motifmempertimbangkan ciri khas daerah dari aspek warna, pola, komposisidan jenis bahan yang digunakan.

b). Partisipasi Mitra

Partisipasi mitra dalam proses pelaksanaan program PKM ini adalah sebagai pendamping, dan berpartisipasi dalam menyebarkan undangan/ mensosialisasikan, serta memotivasi para perajin untuk ikut dalam program PKM ini. Selain itu mitra juga bertanggungjawab dalam penyediaan tempat untuk dilakukan pelaksanaan pelatihan ini.

\subsection{Pendampingan}

a). Metode Pelaksanaan

Tim pelaksanaan kegiatan dibantu oleh masyarakat, memantau danmengevaluasi hasil sosialisasi dan pelatihan setiap minggu. Salah satu alatmonitoring dan evaluasi adalah menyebarkan kuesioner kepadamasyarakat sasaran yaitu perajin rendo bangku di Koto Gadang. Pendampingan dilakukanuntuk seluruh perajin sasaran sesuai dengan kapasitas masing-masing.

b). Partisipasi Mitra

Mitra berpartisipasi dalam pendampingan sebagai tempat berkonsultasi.Mitra berpartisipasi juga dalam memicu kreativitas perajin dan memotivasi anggotanya untuk membiasakan diri mengembangkan desain motifdan produk rendo bangku di Koto Gadang Kabupaten Agam.

\section{HASIL DAN PEMBAHASAN}

Pelaksanaan kegiatan pengabdian kepada masyarakat di Koto Gadang Kabupaten Agam Sumatera Barat telah mulai dilakukan sesuai dengan jadwal yang telah direncanakan. Pengembangan desain motif dan produk rendo bangku telah dapat dilakukan dan menghasilkan beberapa macam desain motif baru rendo bangku dengan ciri khas Minangkabau. Motif untuk alas gelas, rendo tepi, dan alas keramik. Peserta pelatihan terdiri dari anak-anak remaja laki- laki dan perempuan serta ibu- ibu rumah tangga yang juga merupakan perajin rendo bangku Koto Gadang. 


\subsection{Kordinasi Kegiatan Pengabdian}

Penyelenggaraan kegiatan pengabdian ini tentunya tidak terlepas dari koordinasi yang dilakukan oleh tim pelaksana pengabdian dari ISI Padangpanjang, langkah program yang dirancang oleh tim pengabdi adalah: 1) koordinasi 2) Pelaksanaan 3) Evaluasi.

Tahap awal yang tim laksanakan dalam kegiatan pelatihan ini adalah melakukan koordinasi dengan tim pengabdian. Berkaitan dengan hal-hal yang perlu dipersiapkan dimulai dari bahan dan alat yang diperlukan pada waktu pelatihan. (Lihat Gambar 2).

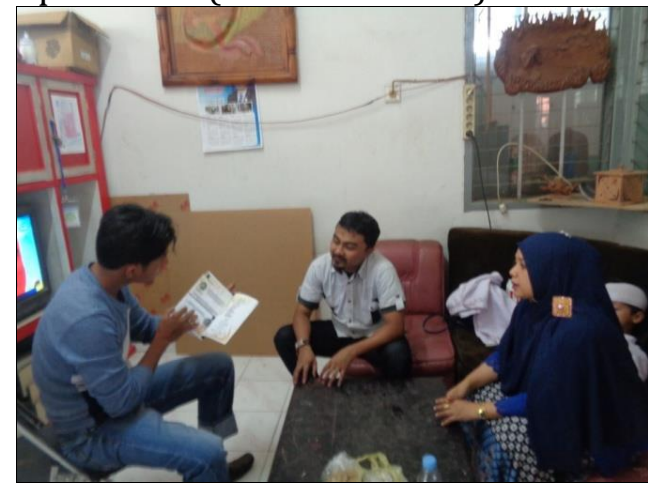

Gambar 2. Koordinasi ketua pelaksana dengan anggota kegiatan pengabdian

\subsection{Pelaksanaan Kegiatan}

Berdasarkan permasalahan yang dihadapi oleh perajin rendo Koto Gadang selaku mitra maka tim pengabdian akan melakukan pengembangan motif dan produk yang lebih kreatif dan inovatif. Untuk meningkatkan kemampuan perajin rendo bangku dalam menghasilkan desain motif dan produk yang kreatif dan inovatif. Adapun alur pelaksanaan kegiatan pengabdian yang tim lakukan adalah :

3.2.1 Koordinasi dengan pengusaha/perajin rendo Koto Gadang

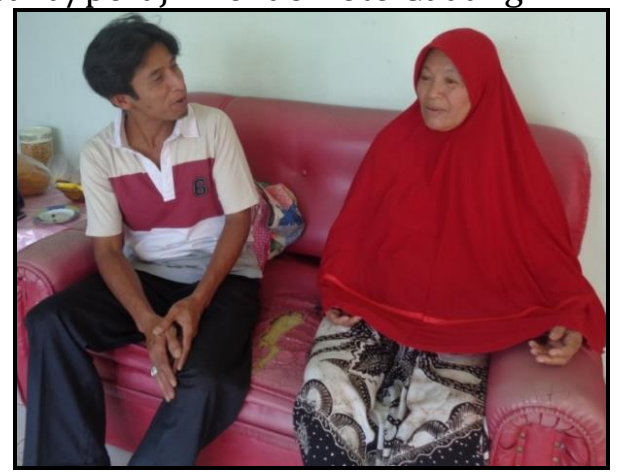

Gambar 3. Koordinasi ketua pelaksana dengan pengusaha/perajin rendo Koto Gadang

\subsubsection{Penyuluhan}

Penyuluhan dilakukan kepada perajin mengenai peningkatan kualitas rendo bangku melalui pengembangan desain motif, pengembangan produk dan pemasaran online dari kerajinan rendo bangku. Karena dengan dilakukan pengembangan desain motif yang berkualitas bisa meningkatkan nilai jual dari produk rendo yang dihasilkan di Koto Gadang.

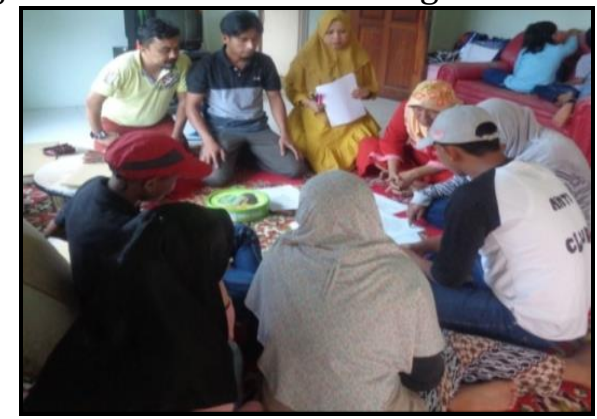

Gambar 4. Penjelasan tim pengabdi kepada perajin rendo Koto Gadang tentang desain kreatif dan inovatif 


\subsubsection{Pelatihan}

A. Persiapan Alat Pengabdian

1. Alat Tulis dan Kertas

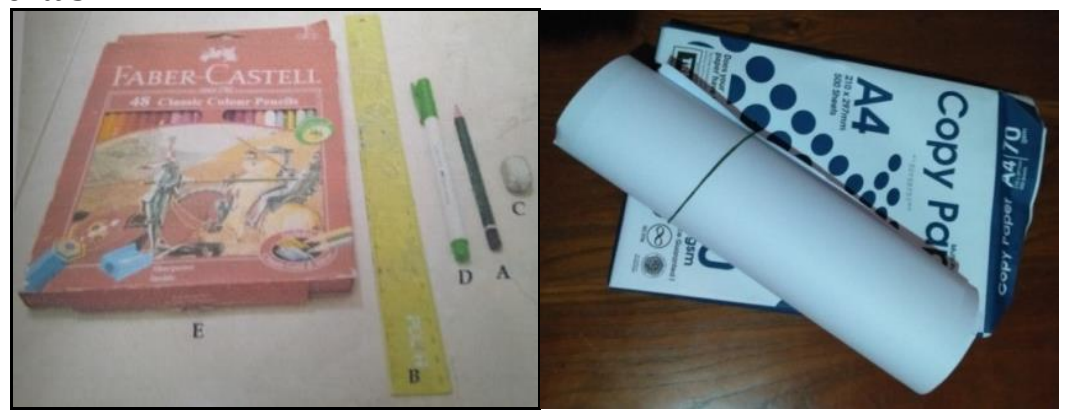

Gambar 5. Alat Tulis, pesil warna dan Kertas HVS ukuran A4 dan A3

2. Bangku Berbentuk Bulat

Bangku ini merupakan peralatan utama yang dipakai dalam pembuatan rendo bangku. Bangku ini dibuat bulat atau bundar dengan memakai alas triplek di isi serbuk didalamnya. Kemudian ditutup dengan kain katun warna putih yang berfungsi sebagai tempat dimana rendo akan dibuat (Ranelis, 2016: 25-26).

\section{Bangku Persegi}

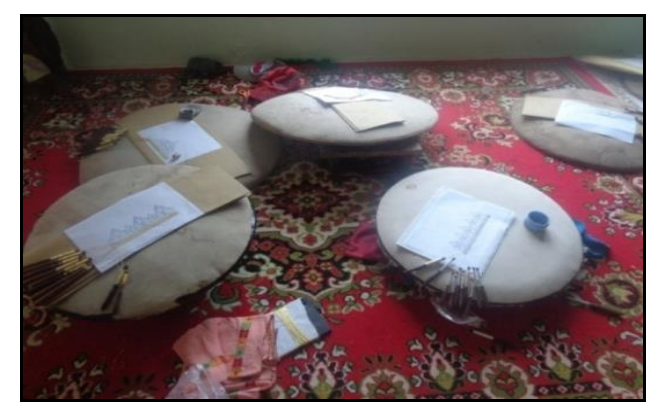

Gambar 6. Bangku bulat tempat merendo yang besar

Bangku terbuat dari triplek yang ditutup kain berbentuk 4 persegi dan dikasih lobang di tengah kain, untuk rendo yang panjang dan berukuran kecil dan panjang.

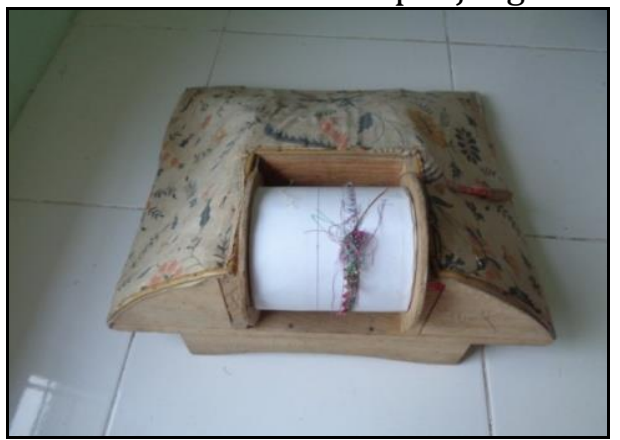

4. Klos

Gambar 7. Bangku persegi tempat merendo yang panjang dan berukuran kecil

Klos adalah alat yang digunakan sebagai tempat benang yang akandirendo.

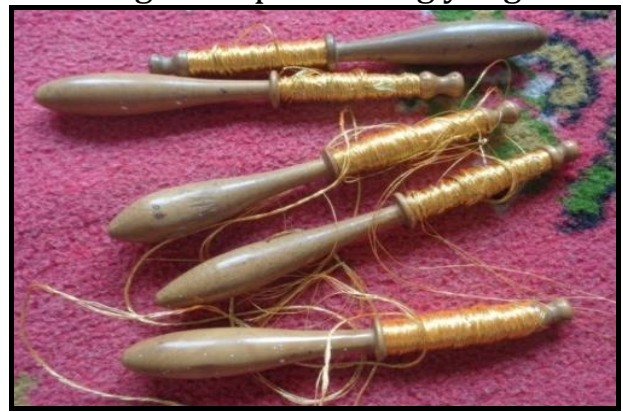

Gambar 8. Klos 
B. Persiapan Bahan untuk Kegiatan Pengabdian

Bahan yang digunakan dalam pembuatan rendo ini adalah : Benang Makau, Benang Suto, Benang DMC dan Benang Border.

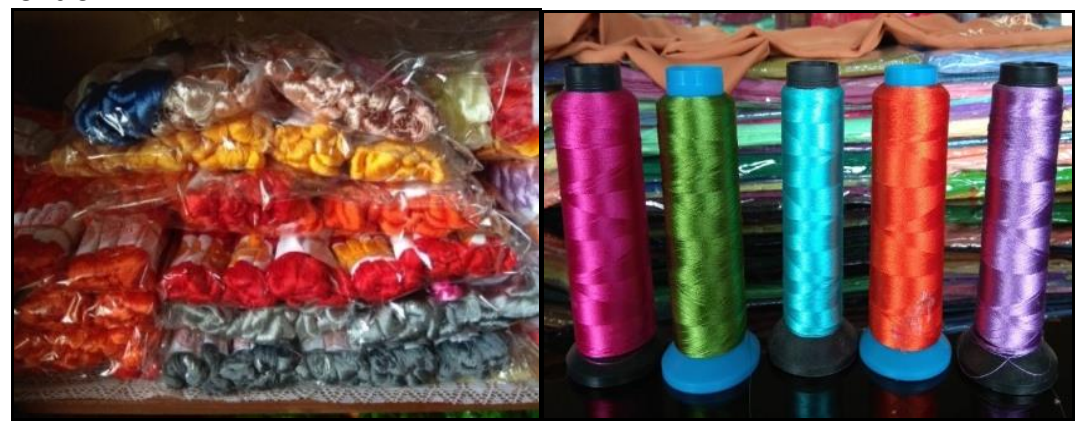

Gambar 9. Benang suto, Benang DMC, dan Benang bordir.

C. Pembuatan Desain Motif dan Produk Rendo Bangku

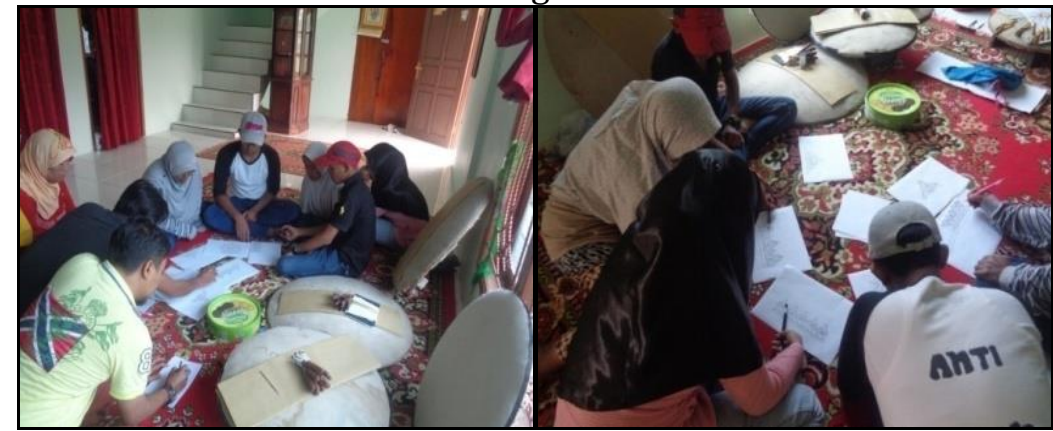

Gambar 10. Pembuatan Desain Motif dan Produk yang Kreatif dan Inovatif

Desain motif yang diberikan kepada perajinan adalah pengembangan dan gabungan dari beberapa motif Minangkabau yang sudah dikreasikan. Desain-desain motif rendo bangku yang dapat dihasilkan dalam program pengabdian ini adalah:

1. Motif panca matohari jo kaluak baralun

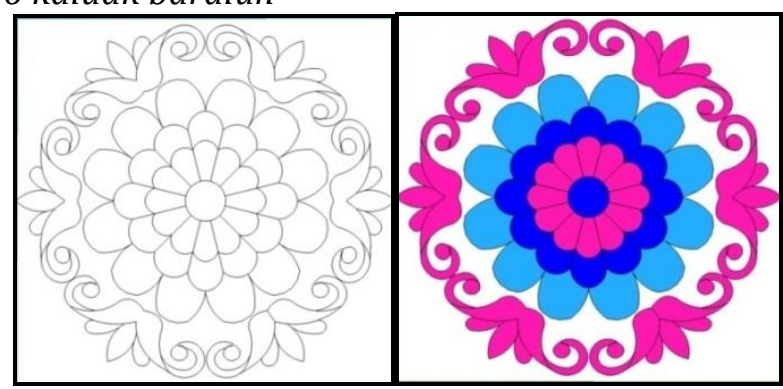

Gambar 11. Motif panca matohari jo kaluak baralun

2. Motif kreasi bungo taratai jo daun bodi

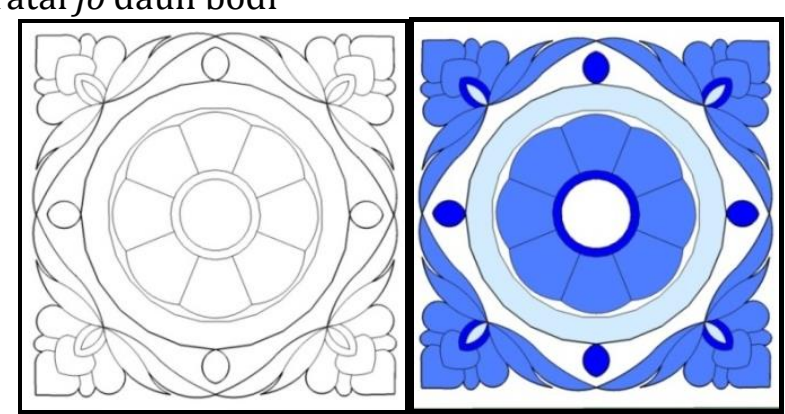

Gambar 12. Motif Kreasi Bungo Taratai Jo Daun Bodi 
3. Motif siku-siku

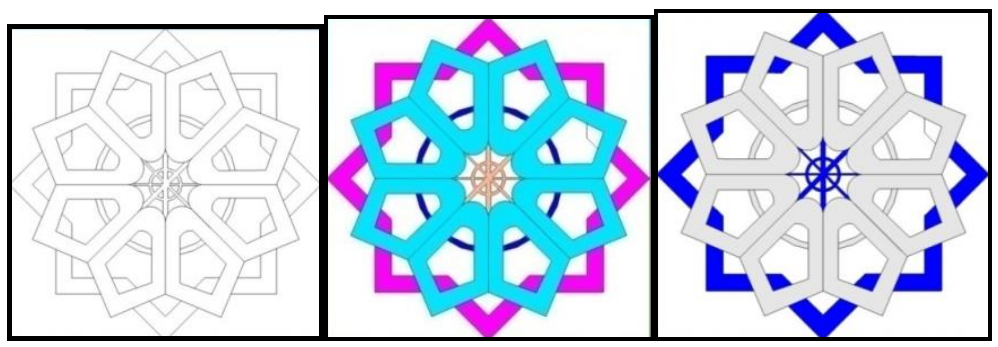

Gambar 13. Motif Siku-Siku

4. Motif siku jo saik ajik

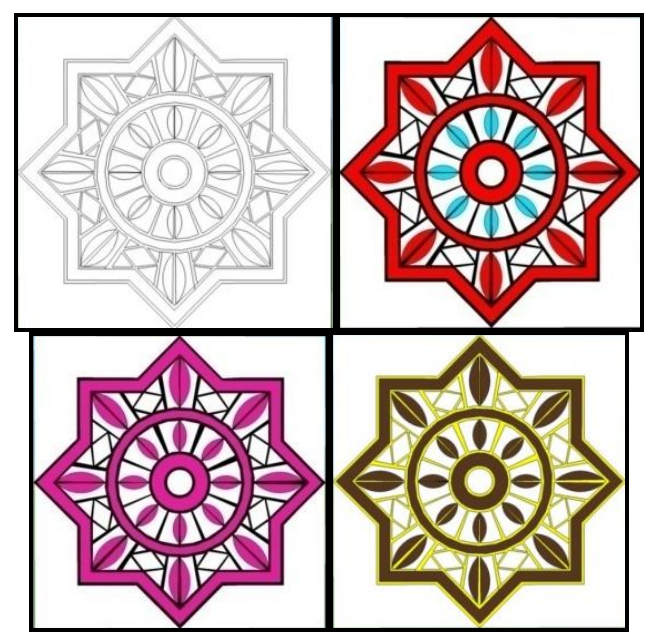

Gambar 14. Motif siku-siku jo saik ajik

5. Motif saik ajik jo siku-siku

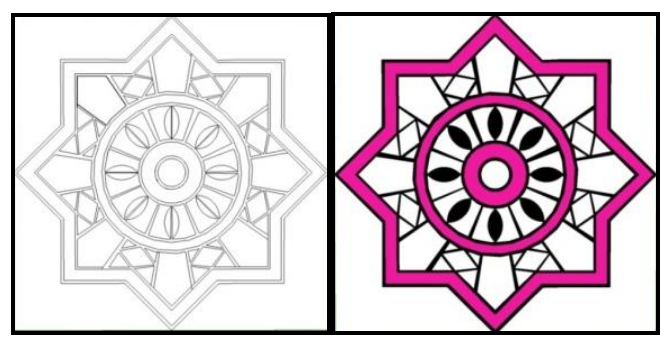

Gambar 15. Motif saik ajikjo siku-siku

6. motif itiak pulang patang jo saik ajik

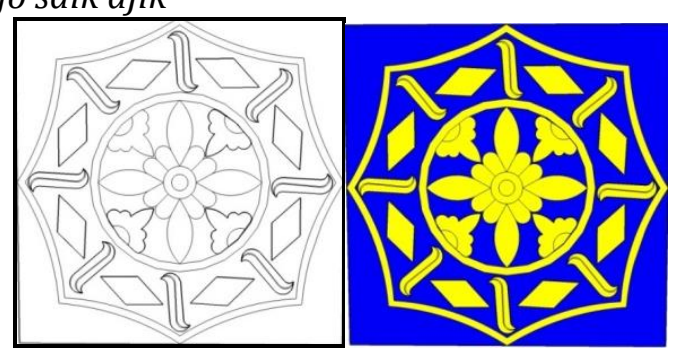

Gambar 17. motif itiak pulang patang jo saik ajik

7. Motif kreasi pucuak rabuang duo jo bungo melati
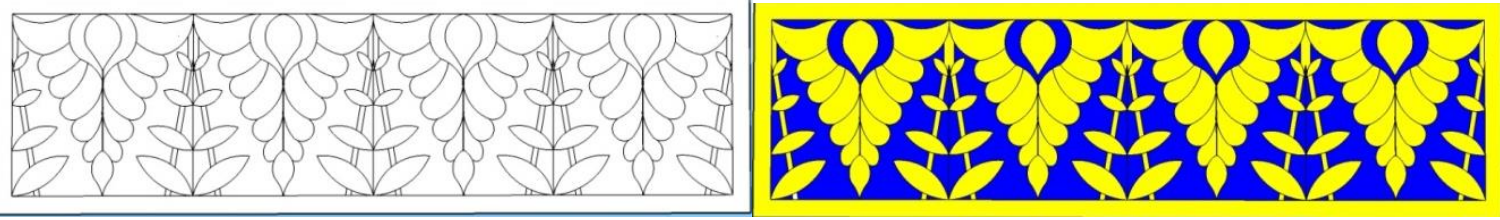

Gambar 18. Motif kreasi pucuak rabuang duo jo bungo melati 
8. Motif saik ajik babungo

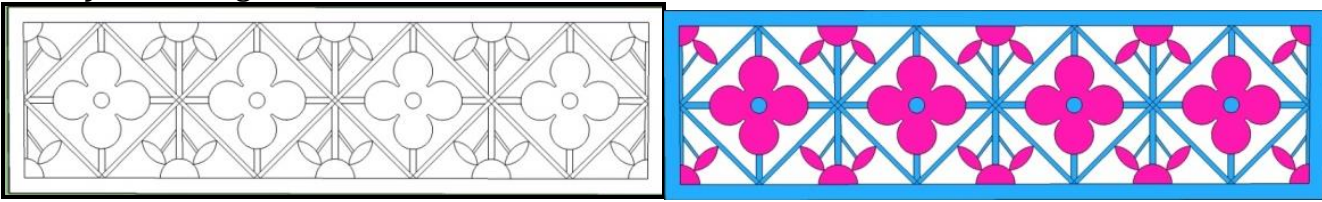

Gambar 19. Motif saik ajik babungo

9. Motif kreasi daun bodi

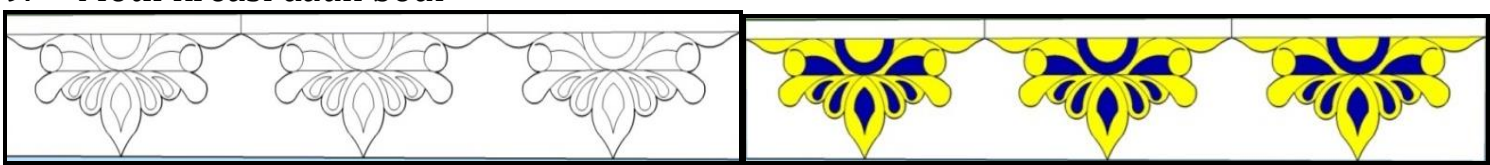

Gambar 20. Motif kreasi daun bodi

10. motif bungo tulip jo bungo melati

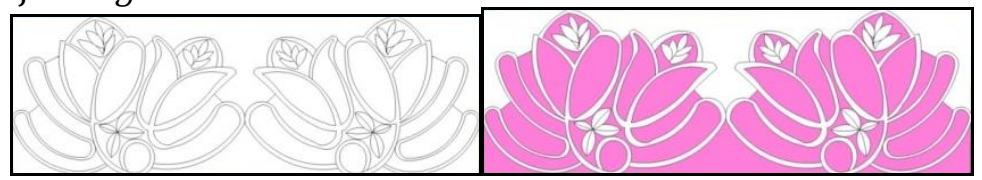

Gambar 21. Motif bungo tulip jo bungo melati

11. Motif kreasi tirai ampek angkek

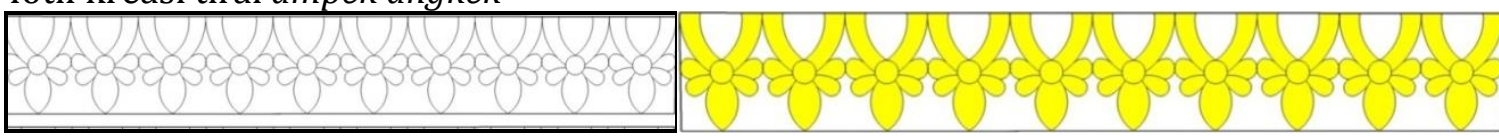

Gambar 22. Motif kreasi tirai ampek angkek

12. Motif kreasi pucuak rabuang satu

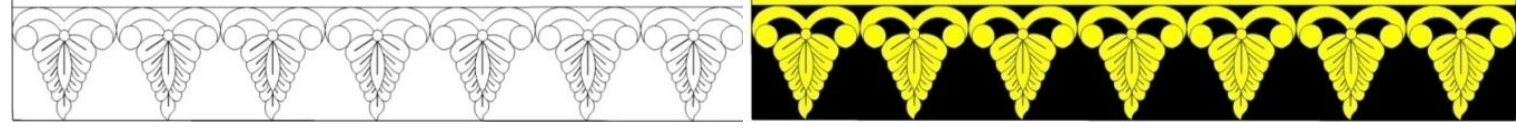

Gambar 23. Motif kreasi pucuak rabuang satu

D. Proses Pembuatan Rendo Bangku

1. Pembuatan desain motif rendo

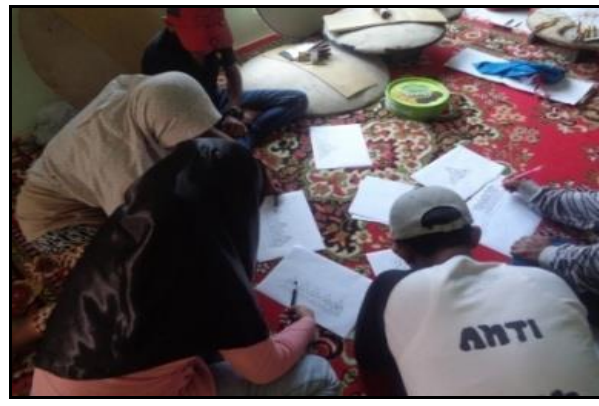

Gambar 24. Pembuatan Desain Motif Rendo

2. Pemasangan motif ke alat rendo

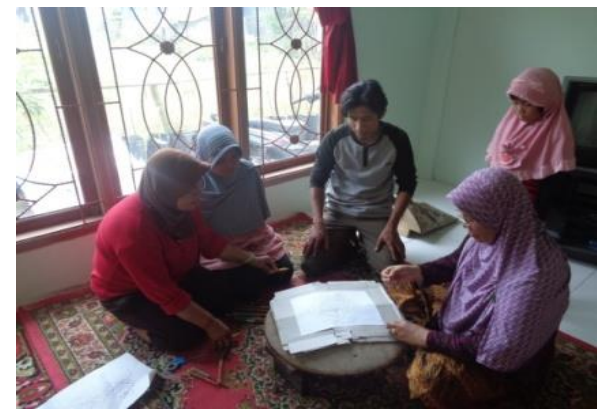

Gambar 25. Pemasangan motif ke alat rendo 
3. Pemasangan benang ke alat rendo dan proses merendo

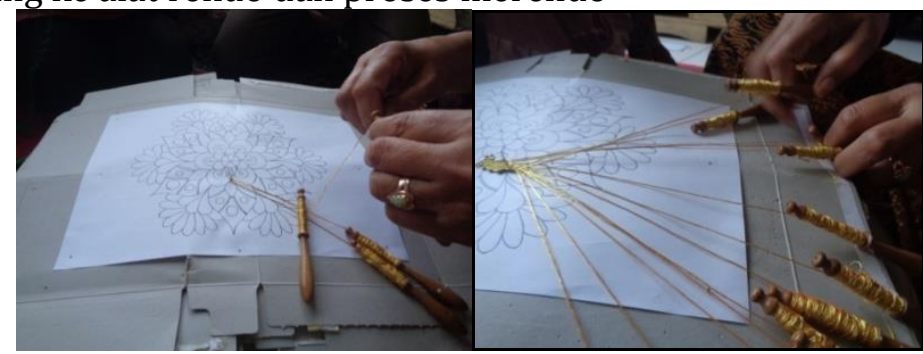

Gambar 26. Pemasangan benang ke alat rendo dan proses merendo

4. Rendo setengah jadi dan hasil jadi (alas gelas )

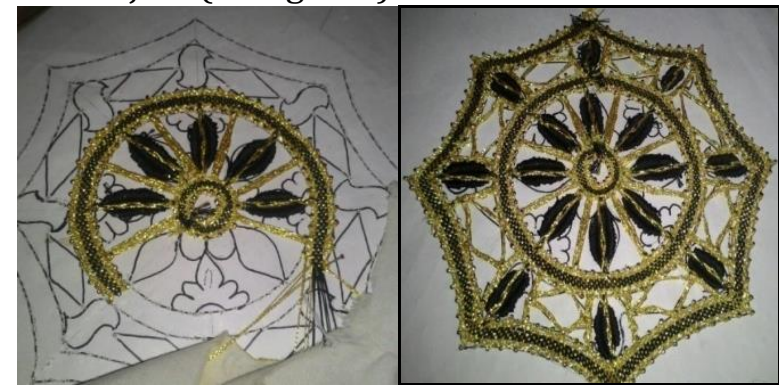

Gambar 27. Rendo setengah jadi dan setelah jadi (alas gelas )

\section{KESIMPULAN}

Kegiatan PKM yang berjudul " PKM Kelompok Perajin Rendo Bangku Di Nagari Koto Gadang Kabupaten Agam Sumatera Barat". Tujuan kegiatan PKM ini adalah memberikan pelatihan pengembangan desain motif dan produk, untuk meningkatkan daya saing di pasar global ataupun internasional dan juga untuk meningkatkan taraf hidup perajin rendo bangku Koto Gadang. Metode pelaksanaan dilakukan dengan cara ceramah dan demonstrasi yaitu memberikan pemahaman dan penjelasan kepada perajin bahwa perlu sekali dilakukan pengembangan desain motif dan produk rendo bangku di Koto Gadang untuk meningkatkan kualitas dari kerajinan rendo bangku yang dihasilkan oleh perajin Koto Gadang dengan ciri khas daerah Minangkabau. Memberikan penjelasan kepada perajin tentang peralatan yang dibutuhkan untuk melaksanakan kegiatan tersebut. Peralatan yang dibutuhkan adalah perangkat desain.

Peningkatan kualitas desain motif dan produk pengembangannya dilakukan dengan cara berinovasi, dengan membuat desain-desain yang baru dengan cirri khas Minangkabau. Pelatihan peningkatan kualitas dan pengembangan desain motif dilakukan dengan cara demonstrasi langsung pada perajin. Beragam jenis pengolahan motif dan inovasi yang bisa dibuat untuk pengembangan kerajinan rendo bangku Koto Gadang. Untuk pengembangan desain motif mempertimbangkan ciri khas daerah dari aspek warna, pola, komposisi dan jenis bahan yang digunakan. Pengembangan motif rendo yang dapat dirancang dalam kegiatan PKM ini adalah 12 desain motif rendo. Nama -nama antara motif yang berhasil dirancang adalah motif panca matohari jo kaluak paku, motif kreasi bungo taratai jo daun bod, motif siku-siku, motif siku-siku jo saik ajik, motif saik ajik jo siku-siku, motif kreasi pucuak rabuang 2, motif itiak pulang patang jo saik ajik, motif kreasi pucuak rabuang 2, motif saik ajik babungo, motif bungo tulip jo bungo melati, motif kreasi tirai ampek angkek, dan motif kreasi pucuak rabuang 1.

\section{UCAPAN TERIMA KASIH}

Tim pengabdian kepada masyarakat mengucapkan puji dan syukur yang sebesar-besarnya kepada Allah SWT yang telah melancarkan kegiatan kami dari awal sampai akhir. Kemudian tidak lupa ucapkan terima kasih kepada Ristek Dikti yang telah memberikan dana untuk kegiatan PKM ini. Terimakasih juga buat LPPMPP ISI padangpanjang yang telah memfasilitasi dalam kegiatan administrasi kegiatan PKM. Terima kasih juga kami ucapkan kepada Ibu Denny selaku Mitra dalam kegiatan PKM yang telah bersedia untuk meluangkan waktu dan tempat untuk pelaksanaan kegiatan 
pengabdian ini, dan para peserta pengabdian yang selalu mengikuti kegiatan pengabdian dari awal sampai akhir kegiatan pelaksanaan PKM.

\section{DAFTAR PUSTAKA}

Esde, Erni, et al. (1994-1995), Kerajinan Sulaman Sumatra Barat, Musium Negeri Sumatra Barat "Adhityawarman", Padang, Departemen Pendidikan Dan Kebudayaan.

Marah, Risman, Ragam Hias Minangkabau. (1987-1988), Jakarta, Departemen Pendidikan dan Kebudayaan Direktorat Jendral Kebudayaan.

Razni, Sita Dewi, Mity J. Juni, dan Rebecca Dahlan. (2005), Pakaian Tradisional Koto Gadang, Bukittinggi, Penerbit Yayasan Kerajinan Amai Setia.

Ranelis, Washinton, Rahmad. (2016), Rendo Bangku Koto Gadang, Padangpanjang, Penerbit ISI Padangpanjang. 